\title{
Evaluating the Dispositions of Teacher Education Candidates: A Place for Self-Assessment
}

\author{
Amneh Al-Rawashdeh, ${ }^{*}$ \\ Yarmouk University, Jordan \\ Gary Ivory \& Jeanette H. Writer \\ New Mexico state University, USA \\ Received: 28/12/2016 \\ Accepted: 23/2/2017
}

\begin{abstract}
The study explored how New Mexico State University (NMSU) teacher candidates understand the assessment form, the assessment process, and the meaning of dispositions assessment according to NCATE standards as related to their development of professional dispositions. The study utilized a qualitative methodology. We used the focus group method with four groups: elementary $(\mathrm{N}=3)$, secondary $(\mathrm{N}=10)$, early childhood $(\mathrm{N}=6)$, and special education candidates $(\mathrm{N}=4)$. We asked teacher candidates about their understanding of dispositions and the dispositions assessment process at the beginning of their program and at the end of their program. Based on the analysis, we found that self-assessment of dispositions at this institution is well-grounded conceptually, and the teacher education candidates found the process to be meaningful to them, but that teacher education candidates' perspectives suggest it has been flawed in execution. We conclude with recommendations both for the teacher education program we have studied and for teacher education accreditation agencies.
\end{abstract}

Keywords: Dispositions assessment, teacher education program, accreditation.

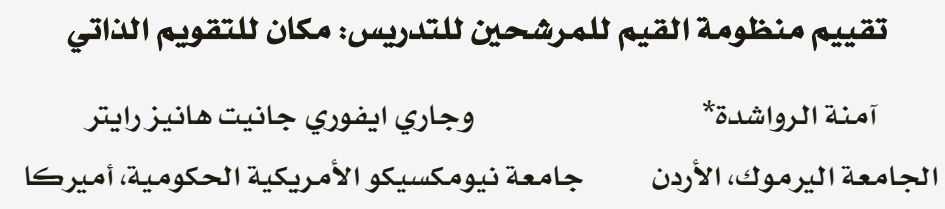

مستخلص: بحثت الدراسة ِّْ فهم الطلاب المعلمـين ِِّ جامعة نيو مكسيكو الامريكية الحكومية لعناصر الاعتماد الثلاثة التالية: نموذج التقييم وعمليات التقييم وتقييم توجهات الطلاب نحو منظومة القيم والاخلاق المهنية للمدرسين بناء على معايير المجلس الوطني

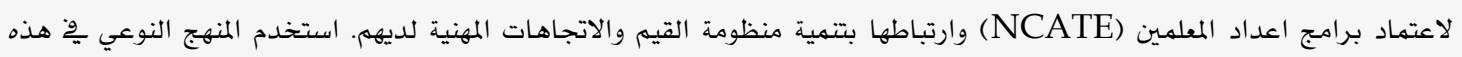
الدراسة ـ تم استخدام منهجية المجموعات المركزة حيث اجريت مع اربعة مجموعات واحدة من كل من التربية الابتدائية وتضمنت اعت المعن المجموعة r مشتركين (ن=r) والتربية الثانوية (ن= • () والطفولة المبكرة (ن=7) والتعليم الخاص (ن=ع). لقد تم توجيه الاسئلة للطلاب

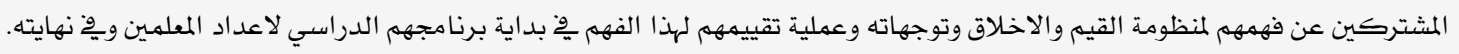
بناء على تحليلنا وجدنا ان التقييم الذاتي للطلاب فِّ هذه الجامعة يمتاز بالعمق المفاهيمي والفلسفي الواضح والطلاب وجدوا ان عمليات التقييم كانت مفهومة ومعبرة. وخلصست الدراسة بتوصيات لكل من برامج اعداد للمعلمـين ومؤسسات التقييم والاعتهاد المشـرفة على برامج اعداد المعلمين. الكلمات المفتاحية: تقييم منظومة القيم والاخلاق للمدرسين، برامج اعداد المعلمسين، معايير الاعتماد التربوية. *a.rawashdeh@yu.edu.jo 
The National Council for Accreditation of Teacher Education (NCATE) and the Teacher Education Accreditation Council (TEAC) have consolidated into the Council for the Accreditation of Educator Preparation (CAEP). CAEP's commission adopted NCATE's inclusion of dispositions as requisite for effective teachers. Dispositions are the "professional attitudes, values, and beliefs" that "support student learning and development" (NCATE, 2008, pp. 89-90). In 2002, NCATE accreditation standards required teacher education programs (TEPs) to both "articulate" and "systematically assess" candidate dispositions (p. 19). CAEP calls for an adequate, reliable, and valid instrument to assess dispositions. While this requirement is pushing many institutions to focus on dispositions assessment, the critical issue to consider in this phase is that although assessment is important, the development of dispositions should be of most concern in teacher education to ensure the preparation of effective teachers (Carroll, 2005; Diez, 2006).

\section{Background to New Mexico State Universi- ty's Teacher Preparation Program}

New Mexico State University (NMSU), in the southwestern United States, is a HispanicServing and Minority-Serving Institution. Although 23 tribal nations are within the state's boundaries, the two largest ethnic groups at NMSU are Hispanic (49\%) and White $(33 \%)$ students (NMSU Fact Book, 2013). “Tribal nations" refers to the hundreds of distinct communities of tribal peoples who are indigenous to what is now the United States. Although Europeans, through invasion and colonialism, attempted to extinguish these peoples, they continue to govern themselves and practice their spiritual, linguistic, cultural, and knowledge traditions. Hispanic students come from families who have been in the state and region for hundreds of years, and from families who are recent arrivals to the United States; many students are Spanish speaking. NMSU serves students both from urban areas of the state and from rural or farming and ranching communities. The institution also hosts a significant population of international students. Numerous students receive some form of need-based financial aid (NMSU Fact Book, 2013).

The Teacher Education Program (TEP) includes the College of Education (CoEd) and the College of Arts and Sciences, with the
CoEd's Department of Curriculum and Instruction (C\&I) having the most responsibility for dispositions development and assessment. C\&I's mission statement reads in part:

We envision and enact dispositions, competencies, and pedagogies that will build and sustain social justice communities within geopolitical, socio-cultural, and historical contexts. These contexts inform how knowledge is shaped and represented, transforming classrooms, schools, and communities. (Department of Curriculum and Instruction, 2012).

Through its mission statement one comes to understand that $C$ \&I is anchored in multicultural education and a social justice perspective of curriculum and pedagogy. This anchoring positions the department to prepare teachers who practice transformative education for the benefit of their students and the students' communities. To do so, teacher candidates are expected to take risks, challenge the status quo and learn "about themselves, their social roles, and the necessity of that process for their socio-cultural and socio-political transformations" as they come to understand the intersections of race, ethnicity, nationality, class, gender, language, gender orientation, sexuality, diverse abilities, and many other hidden or seemingly invisible manifestations.

The theoretical and philosophical stance of the department is based in critical multicultural education, critical pedagogy, and social justice; tied specifically to the work of Paula Freire (1970). Although a wealth of scholarship has been developed by scholars of multicultural education (Banks \& Banks, 2001; Baptiste \& Boyer, 1996; Bennett, 2001; May 1999; Sleeter\& Grant, 1987), a definitive definition does not exist. For purposes of this article, we rely on Nieto and Bode's 2008, p. 44) definition:

Multicultural education is a process of comprehensive school reform and basic education for all students. It challenges and rejects racism and other forms of discrimination in schools and society and accepts and affirms the pluralism (ethnic, racial, linguistic, religious, economic, and gender, among others) that students, their communities, and teachers reflect. Multicultural education permeates schools' curriculum and instructional strategies as well as the interactions among teachers, students, and families and the very way that schools conceptualize the nature of teaching and learning. Because it uses critical pedagogy 
as its underlying philosophy and focuses on knowledge, reflection, and action (praxis) as the basis for social change, multicultural education promotes democratic principles of social justice.

To operationalize their mission statement, the C\&I faculty moved to develop in their teacher candidates' professional dispositions so they would develop as effective and culturally responsive pre-service teacher candidates and in-service teachers. The faculty identified five characteristics (caring, equitable, professional, responsible, and socially just) and developed the dispositions form to assess them through a deliberate and time-intensive process.

To emphasize growth in each of these dispositions and each specific indicator of the dispositions, in the assessment process, candidates were to identify themselves and be identified by their course instructors as falling into the categories of awareness, developing, or praxis (insert link to the dispositions-assessment form). The category of awareness indicated that students possessed and were able to demonstrate a new consciousness, perspective or concept. The category of developing indicated that students were processing and analyzing meaning, sense or connection. Praxis was defined as "reflective application." Praxis was considered the highest level of demonstration. Freire (1988) described praxis as "reflection and action upon the world in order to transform it" (p. 36).

NCATE has required dispositions assessment though its standards of "Candidate Knowledge, Skills, and Professional Dispositions" and "Assessment System and Unit Evaluation" (2008a, pp. 12-13). NCATE maintained that caring and qualified teachers could help students learn basic skills along with the skills and knowledge of how to become responsible citizens.

Upon the consolidation of NCATE and TEAC into CAEP, the CAEP Commission on Standards and Performance Reporting (CAEP Commission, 2013) specifies that teacher preparation programs must monitor attributes and dispositions beyond academic ability that candidates must demonstrate at admissions and during the program The provider selects criteria, describes the measures used and evidence of their reliability and validity of those measures, and reports data that show how the academic and non-academic factors predict candidate performance in the program and effective teaching (p. 9).

\section{Review of Literature}

\section{Dispositions Assessment}

A review of the dispositions literature reveals the consideration and assessment of dispositions to be more complex and controversial than NCATE and CAEP standards would suggest. Pessimistically, Haberman (1991) maintained that certain forms of multiculturalism could not even be taught in TEPs as they existed at the time. He asserted that the best that institutions could do without substantial change was to select candidates who had what he called "cultural awareness" (p. 25) before they entered TEPs. Haberman and Garmon (2005) emphasized that the attitudes candidates brought with them to TEPs had substantial influence on what dispositions they would develop in those programs; they in effect, questioned the influence that TEPs have on dispositions development.

But other scholars have emphasized that TEPs must do what they can to develop dispositions in teacher candidates (Carroll, 2005, 2012; Gay \& Kirkland, 2003). Duplass and Cruz (2010) cite a number of scholars who claim that "with the right set of conditions, people can be motivated to change their disposition and their behavior" (p. 141). Buchman (1993) saw candidates as having to shift their orientation from the person to the role: "a shift of concern from self to others comes more from acknowledging, 'This is the kind of work I am doing,' than from stating 'This is how I feel' or 'This is how I do things'" (p. 148). In fact, Haberman's (1991) pessimistic argument was not so much that dispositions should or could not be developed, but rather developing them was impractical, given current conditions and resources in units of teacher preparation. Diez (2006) maintained, "Assessment can play a major role" (p. 65) in dispositions development.

Given the lack of resources in units of teacher preparation, Duplass and Cruz (2010) listed a number of issues that complicate the process of assessing dispositions. Four of the most salient for our purposes are: (a) the difficulty of assessing dispositions thoroughly and accurately, given faculty's limited contact with 
students and the range of other responsibilities assigned to professors; (b) the fact that dispositions develop over long periods of time and that they may be demonstrated only when the right opportunities arise; (c) controversy about which kinds of data to use to assess dispositions: quantitative or qualitative; and (d) the potential for legal liabilities that could arise when a candidate is removed from the program because s/he lacks the "right" dispositions. The CAEP Commission, (2013) states forthrightly, "Research has not empirically established a particular set of non-academic qualities that teachers should possess" (p. 11). The last item, though perhaps not the most important in Duplass and Cruz's (2010) list, is pertinent given our mention above of CAEP's current requirement to use assessments of known and adequate reliability and validity. Documenting reliability and validity is accomplished more readily with quantitative data. Diez (2006) questioned - as do we-the assumptions behind and implications of dispositions assessment processes that overemphasize presumed objectivity, the breaking of dispositions into discrete components, and standardization of expectations of observable behaviors.

Despite legitimate concerns that might be raised about CAEP's emphases in the process of dispositions assessment, CAEP does seem in sync with NMSU faculty's consideration of and response to diversity. The CAEP Commission on Standards and Performance Reporting endorses the Standards of the Interstate Teacher and Support Consortium (INTASC) which "contain literally scores of references to cultural competence, individual differences, creativity and innovation and working with families and communities" (CAEP Commission, 2013, p. 21). Our study builds on the literature we refer to here to deepen understanding of how assessment of dispositions can be a contributor to dispositions development, particularly with regard to diversity and multiculturalism that has shaped the vision and mission of the department on Curriculum and Instruction on this study.

\section{Assessment of Dispositions as related to Pro- fessional Development}

Our review of the literature revealed two factors to which teacher educators need to attend if dispositions assessment is to support dispositions development. The first factor to consid- er is self-reflection. According to Diez (2006), dispositions assessment needs to be part of an ongoing reflective process to support dispositional development through reflection, feedback, and providing documentation of performance. Wilson, Thornburg, and Riley (2005) stated that, "Teacher educators should first assist candidates in becoming conscious of their dispositions, find out what they want to change, and then create circumstances in which they can begin this development transformation" (p. 1). In addition to classroom support, Koerner (1992) stressed that teacher educators need to support the development of dispositions through student teaching because student teaching is an evolution from preparing to be teachers to professional practice and reflection on teaching. Breese and NawarockiChabin (2007) agreed with Koerner, but added "our role as teacher educators is to structure opportunities for candidates to examine the relationships among teacher behaviors, their impact on teaching and learning, and the dispositions such behavior signals to students, colleagues, administrators, and parents" ( $\mathrm{p}$. 34).

The second factor to consider in supporting dispositions development is that dispositions assessment should be public and explicit (Diez, 2006).Diez proposed that both teacher candidates and teacher educators need to be aware of the exact goal of the assessment in order for teacher candidates to visualize and achieve expected performance, behaviors, and attitudes. Diez also recommended that teacher educators have explicit and clear criteria to evaluate teacher candidate dispositions in order to support the candidates' awareness, reflection, and development of their dispositions.

Therefore, we note that teacher candidates' self-assessment of their own dispositions might foster self-reflection, which can support dispositions development. We emphasize that in order for self-reflection to occur, teacher candidates need the opportunity to utilize and continuously reflect on each disposition within a dialogical process with professors/instructors and student colleagues in the classroom context. The opportunity for dialog fosters moving into praxis by creating connections between course content (knowledge) and one's practice or potential practice. As such, research on candidate self-assessment should examine the extent to which it is meaningful to 
them and thus, can be a catalyst for reflection and introspection.

Role of Assessment in Dispositions Development: The Case of New Mexico State University

According to the literature, the mere assessment of teacher candidate dispositions is not a sufficient condition for dispositions development. We contend, however, that assessment could be carried out in such a way as to foster introspection and reflection, consequently contributing to dispositions development. To provide evidence for our claim, we move now to our study.

In alignment with NCATE/CAEP's requirement that TEPs assess dispositions, and despite NCATE's urging that dispositions be based on observation of candidates in their clinical experiences, NMSU developed a system based on teacher candidates' selfassessment of their own dispositions. To facilitate the process NMSU teacher candidates selfassessed their dispositions at several points during their progress through the TEP. However, up to this point, NMSU faculty has lacked knowledge of candidates' reactions to this assessment. As such, the faculty cannot tell in any systematic way how meaningful teacher candidates find the dispositions assessment currently in place, and therefore, cannot tell to what extent the dispositions assessment process contributes to introspection and self-reflection. As researchers, we explored in this study how teacher candidates understand the assessment form, the assessment process, and the meaning of dispositions assessment as related to their development of professional dispositions.

\section{Method}

\section{Qualitative Design}

Our study explored teacher candidates understanding of the dispositions and the disposition assessment process according to NCATE as related to their development of professional dispositions on the department of Curriculum and Instruction (C\&I) at New Mexico State University (NMSU). We used qualitative research to elicit teacher candidate's understanding of the dispositions assessment process, specifically focus group interviews. Qualitative research is based on the premise that "knowledge is obtained by participating sub- jectively in a world of meaning created by individuals. What exists is what people perceive to exist" (Kirby, Greaves, \& Reid, 2006, p. 14). Hence, we assume that meaning is socially constructed by individuals in an interaction with their world where realities are not fixed, singular, or measurable phenomena (Merriam \& Associates, 2002). Our research explored how teacher candidates understand the assessment form, the assessment process, and the meaning of dispositions assessment as related to their development of professional dispositions.

To acknowledge our "researcher as instrument" (Kirby, Greaves, \& Reid, 2006) positionality within the qualitative paradigm and to represent the multiple realities present within this study, we must identify ourselves. Two of us, referred in this article as "author/researchers", interacted with the teacher candidates through the focus-group interviews while the third author was central to the development of the dispositions assessment form and process, and used the assessment in a course. The third author did not moderate the focus group interviews, nor have any contact with the teacher candidate participants.

\section{Focus-Group Interviews}

The focus group interview provides a comfortable environment for a group of participants who possess specifically identified characteristics. Participants share their perceptions on a topic or phenomenon with the researcher or researchers in focused discussion. The data gained from this method may offer an accurate reflection of group members' views because the researchers, serving as moderators, do not mediate power. The researchers facilitate a discussion or conversation between the participants, and strive to avoid showing approval or disapproval of what they say; there is no compulsion to tell a story to please the moderator since all types of comments are welcomed into the discussion. Participants are encouraged to speak honestly and openly (Krueger \& Casey, 2000).

\section{Data collection}

Since, consistent with the expectations of the developers of the assessment instrument, we suspected that candidates' understandings developed over time, we decide to interview NMSU teacher candidates at the entry level 
and exit level. Entry level refers to candidates who had completed the dispositions assessment form for the first time or second time but had not yet been admitted into the TEP. The exit-level group consisted of teacher candidates who were completing their student teaching semester and completing the form for the last time. The focus group participants, for both levels, were recruited in person by one of the author/researchers visiting multiple university classes and sharing with the teacher candidates the purpose of the study and asking if they were willing to participate in the study. Participation was voluntary. We did four focus-group interviews: Entry level, elementary $(\mathrm{N}=3)$, Entry level, special education $(\mathrm{N}=4)$, Exit level, secondary $(\mathrm{N}=10)$, and Exit level, early childhood $(\mathrm{N}=6)$. Each focus group was tape recorded and transcribed.

This study is limited to a state university in the south west of the United States that serve minority students. Also the limitation resides within the fact that department of Curriculum and Instruction have developed its dispositions from according to the multicultural education tenants but in compliance with NCATE standards.

\section{Moderating the focus groups}

In conducting the focus group interviews the authors/researchers, as moderators, welcomed the participants and presented to them the purpose of the study and the ground rules of the focus group. Participants were also provided with a copy of the NMSU Dispositions Self-Assessment Form. The teacher candidates had recently completed the form, but providing the form during the focus group allowed them to refer to the form throughout the discussion. Based on Krueger and Casey's (2000) recommendations, we, asked similar types of questions for each focus group. Additional questions and prompts were used if needed for clarification and to elicit elaboration from participants. The focus groups lasted from 60 to 90 minutes.

Listed are the focus group questions:

- What's the first thing that comes to your mind when you hear the phrase, "teacher dispositions"?

- What part of the dispositions assessment seems good to you? And what makes it good?
- What part of the dispositions assessment seemed disappointing to you? And what made it disappointing?

- Suppose that you were in charge of the TPP program, and were responsible for making sure that TPP candidates have positive dispositions. How would you do it? (For entry-level only)

- Do you feel that your disposition has changed since you started the program? And how? (For exit-level only)

- Our teacher education program is required to assess all of you in knowledge, skills, and dispositions. We want you to help us understand if we are doing a good job of assessing dispositions; and if there is anything that we missed. Is there anything that you wanted to say and didn't get a chance to say?

\section{Data Analysis}

We used an inductive approach based on content analysis (Patton, 1990) as our method of data analysis. This process included each of the two authors conducting the analysis independently and then meeting together to reach consensuses on themes. The process reading and analyzing the data was built on Kruger and Casey's (2000) model of analyzing focus group which considered the followings: words, context, internal consistency, specificity of response, finding big data, and the purpose of the study. In addition, we utilized in coding Kruger and Casey's data analysis method that included: 1) frequency, 2) specificity, and 3) extensiveness. Frequency refers to how frequently something important and related to the purpose of the study is said in the data. Even though we were paying attention to frequency of concepts or words related to the purpose of the study, we were also aware that frequency of utterances should not be our sole criteria-sometimes key insights might have been said only once. Specificity refers to the way we considered the comments that provided details, based on experiences, and were very specific to the purpose of the study. Extensiveness refers to how many different people say the same thing. After discussing our individual coding, we used the coded responses as an organizing frame to classify responses into themes. In the section 
below, we give a description of each theme, present sub-themes, and provide choice quotes that highlight the themes. All student names are pseudonyms. The level entry or exit and the major are indicated at the end of each quotation.

\section{Results}

The findings from the entry and exit level teacher candidate focus groups can be summarized under five major themes:

- The self-assessment process was meaningful.

- Teacher candidates had difficulty understanding the assessment forms.

- Teacher candidates had difficulty understanding the assessment process.

- The dispositions assessment was particularly difficult in online courses.

- Teacher candidates had recommendations for improving dispositions assessment.

\section{The Self-Assessment Process was Meaning- ful}

Some teacher candidates found the selfassessment process to be meaningful in two ways:

The self-assessment process increased awareness of exhibiting positive dispositions.

Specifically, teacher candidates remarked how filling out the forms multiple times raised their awareness and consciousness of exhibiting positive dispositions.

Filling out the dispositions form]is making me look toward the future. Because now even on some of [the dispositions assessments] that I put developing as a student teacher, I focus on that one and I thought, "What can I do to . . . to make a change? To change the future? How can I make sure that I'm always at praxis and I do not go back to developing or awareness?" Because I remember the first time I filled this out, like I said before, I was a little bit panicky because I thought, "Oh, my gosh, I'm not going to be a teacher." So how can I stay at praxis and make sure that I am aware of celebrating diversity in my classroom? That I am aware of the community. (Exit level, secondary) The self-assessment process was meaningful to teacher-candidates in terms of personal and professional growth. In many comments, teacher candidates stated they valued using the dispositions form as a selfassessment instrument to track their own growth toward becoming the teacher they aspire to be. For example, Isabel told us:

[What] I did really like about this process is that you can go back and check over the other ones. And if you still have just like awareness in one thing, it allowed me to look at it and go, "Okay, why do I still just have awareness? What is it that I'm not doing to get to that next step?" So it was a good way to sort of track the progress in certain areas. (Exit level, secondary)

Bethany noted:

But I actually tried to update saying, "Well, have I done this?" "Is there anything I could do differently now that I'm at this level?" "Have I taken more classes and maybe have learned more about what I hope to do in my classroom?" Or, you know, "Am I happy where I am with this? Can I maybe up this a little bit?" (Exit level, secondary)

Gloria added,

You start to really become self-reflective. And then you're like, "Okay, I do see it's important. And I do see myself progressing. But it took a while to get there before I even realized that". (Exit level, secondary)

Polly explained:

When you have those questions in front of you, it gives you the opportunity to reflect on yourself and to think ... really give thought to it and think...: "Do I do this enough? Or do I not do this?" And it helps you like question where you're at (exit level, early childhood).

Laila said:

I think I agree with what [have] been said [about filling the dispositions form] that you're really doing a self-reflection. And that ideally you want-- everything that's cited on the chart, you want to be that. You want to make sure that you have the convictions to state facts - see some evidence, even though or if the consequences are unpleasant. I think it's-- you should reflect back to those moral standards: Are you a good person? Are you 
following through the way you should be? (Entry level, SPED)

Teacher candidates had difficulty understanding the assessment form

Teacher candidates shared that in terms of using and filling out the assessment form they were confused and had a hard time understating the followings aspects of the form:

Some had difficulty understanding the meaning of the term "dispositions" in the assessment form early in the program. Most of the participants expressed that despite the fact that they found the dispositions selfassessment form to be meaningful to them as a future teachers, they explained that early in the program they had not understood the meaning of the term "dispositions. Gloria recalled initially feeling "It was very, very bizarre. Very hard to get a grasp of what they're needing me to fit into [this form]." (Exit level, secondary)

Some teacher candidates had difficulty understanding the rating language on the selfassessment form. Candidates explained that they were confused regarding the rating language where they were supposed to indicate whether they were at awareness, developing, or praxis. Gloria admitted:

We do [the form] four times. And I think three of the times, I've gotten praxis and awareness confused. And so I've had to go through and redo it because I know that as an education person I should know these words. But then I read the definitions, and I'm like, "Oh, praxis is the good one. Wait. Is awareness the good one? Because I'm aware of it and I practice it. No, ... praxis is the good one. (Exit level, secondary)

Teacher candidates had difficulty in understanding the assessment process

Teacher candidates expressed that completing the dispositions form was meaningful to their dispositions development, yet they expressed difficulty in understanding the assessment process and the meaning behind filling out the dispositions form. Here, we have two subthemes:

Some teacher candidates explained they did not know the meaning or the significance of the assessment process. Patricia said,

I was never explained the significance of the dispositions. I was kind of just given it [the assessment form]. You had to do this. There is no explanation; just do it. So if I was given an explanation and the background on the dispositions... it's helpful. I kind of figured it out on my own. I think it would have been more helpful in the beginning to know [the meaning of the assessment process].(Exit level, early childhood)

\section{Gloria noted:}

If you're never told that ahead of time or at the initial time that it's been brought out, you're like, "What is this for? This is not meaningful to me.' In my first two that I did, I had absolutely no idea.(Exit level, secondary)

Teacher candidates shared the difficulty they had in deciding which voice to use while filling out the dispositions form early in the program. They were unsure if they were to use the teacher candidate voice or the future teacher-educator voice. For example, Isabel admitted,

I was confused sometimes of the voice as well, too. Like, should I be [completing the assessment form] as a student or as a teacher/educator? Should I be applying it to this specific class that I'm filling this out for [now], or should it be for the overall big picture?

Demi added,

I think what was confusing about the idea of it being a teacher-candidate disposition is where we answer the questions, like as a student or as a potential teacher. Are we answering it as: Do you go to class? As in, "Do you show up for your... education classes sometime?" Or, is it just education [in general]?Or, is it what you do when you're doing your practicum and that kind of thing? So it's kind of like, what voice to use I guess. (Exit level, secondary)

\section{The dispositions assessment was particularly} difficult in online courses

The teacher education program at NMSU is not offered online due to the department's belief in the importance of students' face-toface engagement with each other and with faculty. However, a few required courses that are pre-requisites for TEP admission are offered through the online format. One such course had been selected for dispositions assessment. From the interviews it was clear that the online courses were a domain that the participants thought were not appropriate for as- 
sessing dispositions. Hilda described her disappointment:

I had to have a disposition done and reviewed by [an online instructor], where I hadn't had a conversation with her. Just very little communication, but yet she's judging me on whether or not she feels that I have all these qualities. And I think that is a huge wrong-huge wrong.. . . I think with these types of values you have to really get to know a person before you can make comments. (Entry level, elementary)

Christine remarked on the absence of dialogue regarding the meaning or purpose of the assessment, "It's . . .even worse on an online course because it is not even an 'Oh let's do this during the class, let everybody kind of talk about it'" (Exit level, secondary).

Teacher candidates provided recommendations for improving dispositions assessment.

Teacher candidates suggested that the TEP can improve dispositions assessment through the following means:

1. Make sure course instructors understand the process of assessing dispositions. Some candidates expressed that it would be of great benefit to them if the instructors explained how to complete the dispositions forms by explaining the rating language, how they should rate themselves, and how the rating will be assessed. Jane advised, "The first time they get the dispositions assessment from, whoever is going to hand this out to them, make sure that they - that the professor or whoever is giving them this document-make sure they tell the student, "You know what? It's okay to be at awareness and developing. . . so you can get to praxis. (Exit level, secondary). She continued, "Because we look at developing and awareness, and I kind of freak out a little bit, I'm not there yet. But, oh, 'my gosh'! Am I going to get in a lot of trouble because I'm not doing it?"

Polly said, I think what makes it difficult is that first during the class, your teacher asks you to send them your dispositions [form] so they can go over it. I think what is discouraging is when you think you are at a level like praxis and they are like, "You are not at praxis. You need to change it. You need to re-word your stuff." So what you think you are at, your teacher might not be [in agreement].

Mari advised also,

I think whenever they give us [ the forms]. . . the first person who gives it out, they should have like a whole meeting focusing on that [if it's supposed to be about self-reflection or not]. I think that's what [should] happens. They don't realize, and they think that we already know. And it's just kind of like... Keep on giving them their work (Entry level. SPED) Dana recommended:

[there is ] no real instruction given by the professor that I was filling it out for, and just, Here you are. And I felt it was completely unchartered territory, and I had no idea what I was doing. And I had no idea at the time. Well, there's no right or wrong. This is my own self-critique and the assistance from my instructor. So, I wish there would have been a little bit more layering to go along with this as far as what it's for--you know, the purpose, and how to do it. And maybe ... just a little more instruction. (Entry level, elementary)

2. Ensure that the classroom instructors or professor provides follow up. Some of the candidates expressed the need for follow up or feedback in timely manner in order to help candidates track their progression or rethink some of the strategies to improve their reflection. Christine pointed out:

The thing that I really didn't like about [the assessment forms] was that they came up occasionally throughout my educational career. But I have no idea what I put on the last one or the one before that or the one before that so I can't track my own progression through these [forms]. They were taken from me and I never saw them again and I don't know what was on them. So I could have praxis on my first one and awareness on the third one. (Exit level, secondary)

I never got feedback for any of my stuff. I would just turn it in. So it got to the point sometimes, too, it was like I'd run into a classmate, 'Oh, yeah, we have a disposition due.' And, you know, I'd just look it up look at my old one. I never get any feedback. "Oh, [name], you're-you have like, you know, 'awareness,' but you should be 'developing' 
right now. And, you know, I- I'm lost on that.

When I had to do dispositions, my teacher did not give it back to me until two months later, afterwards when the class was already over. And she had marked off basically where I thought I was at. She had marked me down below [to the lower category]. And I did not have an opportunity to talk with him, like, why did you think that? So it's hard if the teachers do not give it back in a certain amount of time. Because you can set yourself up to be at this level, but if you really do not know or aren't given an example of what it should look like or how it should be, then that is discouraging.

3. Provide classroom dialogue to discuss dispositions development. Some of the teacher candidates explained that it would be beneficial for growth and selfreflection to engage students in a classroom discussion or dialogue to facilitate reflection on their dispositions. Dennis asserted, "I think the conversation helps to see other people's viewpoint. And make an understanding of it on your own. And kind of reach . . . a point in your own thoughts so that you know where you fall." (Exit level, secondary)

Jane claimed: I strongly believe that if we were to go over them as a group and say them out loud, it will make us think a lot more about them. And once we are student teachers, then we have to fill these [forms] at the end, it will help us a lot more to see how much you have improved or if you have improved a lot.

\section{Discussion}

Reviewing the literature on dispositions assessment, we did not find direct linkage between dispositions assessment and dispositions development. We found literature, however, that suggested self-reflection was linked to dispositions development. We questioned if dispositions assessment might be linked to dispositions development indirectly, i.e., through fostering self-reflection. Therefore, we have conducted four focus groups to explore how teacher candidates understand the assessment form, the assessment process, and the meaning of dispositions assessment and to what extent it fostered reflection. Our findings support the notion that teacher candidates found dispositions assessment a meaningful contribution to introspection and reflection.

It is clear that some candidates found meaning in the process of assessing their own dispositions various times during their program. This is a necessary condition to lead to selfreflection and dispositions development. So, in that respect, we believe that the NMSU TEP is on the right track in using self-assessment to foster dispositions development.

It is equally clear from our data that some candidates encountered difficulties in the process of assessing their own dispositions. The difficulties of not knowing the meaning of "dispositions" early in the program, not knowing which voice to use, and not understanding the language of the self-assessment form lead candidates to not reflect fully on their dispositions, which may have adversely affected the impact of dispositions assessment on dispositional growth or discouraged them in their dispositional development. In the context of the dispositions assessment at NMSU, it would be beneficial that the assessment of dispositions is public and explicit given Diez's (2006) recommendation that assessment of dispositions be clear for both teacher educator and TEP candidates. We propose that faculty attention to clarifying the assessment form's criteria would broaden candidates' understanding of expected behaviors and attitudes, making the self- assessment more meaningful, thus strengthening its link to dispositional development.

Additionally, teacher candidates remarked that having a public discussion or a dialogue about dispositions assessment in the classroom could offer opportunities for growth and self-reflection. Dennis's quote above about making "an understanding of it on your own" indicates that offering a space for dialogue about dispositions assessment offers opportunities for self-reflection and growth. Even though the literature reveals little evidence that discussion or dialogue about dispositions supports dispositions growth, we suggest that teacher educators utilize classroom discussion about dispositions assessment as one approach to enhance self-reflection on dispositions leading to dispositions development. Dialogue assists in forming a synergistic relationship between knowledge, reflection, and action, helping candidates recognize the power they have to transform the world. Con- 
sistent with the views of Freire and Macedo (1987), we urge that in order to fully develop professional dispositions, teacher candidates need to be provided opportunity to speak the dispositional word in an active, engaging dialogue with others. In this instance the significant others are teacher candidate colleagues and course instructors. Accordingly, in regard to the candidates' experiences, the faculty of NMSU must take heed to create space in courses to engage candidates in discussions on the developing dispositions. Doing so will allow candidates to further their teacher dispositions development and ensure the enactment of the departmental mission statement in relation to its foundations of multicultural education and social justice.

It seems clear that the self-assessment is sound in its concept but flawed in its execution. To effectively link dispositions self-assessment to development, TEP candidates must have fuller understanding of the process and its purpose. This requires faculty themselves to have fuller understandings so as to explain the process to candidates and to exploit its potential for selfreflection. Focus group participants told us of faculty who demonstrated little or no such understanding.

We propose that the TEP investigate further to find if certain faculty members (e.g., regular fulltime, adjuncts, and teaching assistants) are not helping students with this process. Then, these instructors must be given instruction in the purpose of the assessment and their role in making it effective. As students suggested, faculty should include in their roles the promotion of dialogue about dispositions, to enhance their development. Since faculty turnover occurs frequently, this instruction must become a regular part of the TEP's responsibilities. Such a sustained faculty development effort will require sustained commitment of time and money. To be meaningful and also to meet accreditation requirements, TEP faculty and staff must come to see dispositions assessment as a main job of teacher preparation, not simply an accreditation requirement with which they must comply.

We do not believe self-assessment of dispositions will fulfill CAEP Commission (2013) requirements that teacher educators provide evidence of the "reliability and validity" (p. 9) of the assessments. Since TEP faculty have in- vested considerable thought and effort in this self-assessment process, and since it appears to show promise in promoting self-reflection, it would seem self-defeating (and excessively compliant) to abandon it. But CAEP requirements seem to make it necessary to implement in addition an assessment that would meet those requirements for documented reliability and validity. Possibly the TEP's selfassessment forms and process could serve a formative role and the new CAEP program/ TEP needs to adopt, for which one can more easily document reliability and validity, could serve as a summative evaluation of candidates' dispositions. It could be administered toward the end of the program, possibly during student teaching.

This leads us to question how narrowly NCATE had prescribed that dispositions assessment be based on "observable behaviors in educational settings" (2008a) and how intensely NCATE and CAEP have emphasized reliability and validity in dispositional measurement. In this sense, we fear that NCATE was and CAEP is expecting teacher educators to assess teacher candidates' dispositions so as to enhance educator quality at the expense of considering the value of dispositions assessment for disposition development. In other words, NCATE and CAEP have emphasized the role of the TEP in certifying the quality of its candidates. This strikes us as a most worthy goal, but efforts to reach it should not be designed so as to crowd out efforts to develop quality. For purposes of dispositions development, real benefit may exist in having candidates assess their own dispositions. Since there is little evidence in the literature that NCATE's , and now CAEP's, approach to the task leads to dispositions development, and given the problems with it cited by Garmon (2005) and Duplass and Cruz (2010), and in light of CAEP's (2013) acknowledgement of the lack of evidence for "a particular set of non-academic qualities that teachers should possess" (p. 11), we believe CAEP should broaden its definition of what constitutes legitimate dispositions assessment.

A striking finding that emerged from the data is the difficulty of engaging students in assessing dispositions in online classes. We find this theme very interesting, especially as many higher education institutions are moving toward online courses. With the institutional 
press for online education, the major question in the context of this study, given CAEP's requirement of dispositional assessment using observable behavior and valid and reliable procedures, is this: how will online TEPs ever adequately comply? Furthermore, even if CAEP accepts NMSU's rationale for relying on self-assessment of dispositions, NMSU's process calls for teacher educators to make observable assessment of each candidate's dispositions. For example, should the candidate rate her or himself at "praxis", but the teacher educator rate the candidate at "awareness", the teacher educator is to meet with the candidate to discuss what must be observed in the candidate's behaviors to rate in the higher category? A physical meeting may be prohibitively difficult in online courses. Our participants' comments also suggest that when assessing dispositions, teacher educators in online courses may carry less credibility with teacher candidates. Based on these observations, TEPs need to carefully select in which classes the assessment form is used to ensure that dispositional assessment actually and actively broadens self-reflection and dispositions development.

In conclusion, we believe that CAEP's inclusion of dispositions assessment has promise for ensuring that TEPs prepare quality teachers for our PreK-12 schools. As Gay and Kirkland argued (2003), dispositions areas important as the "mastery of techniques for instructional effectiveness" (p. 181). At present, teachers are engaged in complex, situational, and cultural contexts that require instructional effectiveness as well as professional values, commitments, and ethics to ensure the educational and personal well-being of all students. Our view of the importance of considering dispositions in teacher preparation is reminiscent of Carroll's (2012) view of dispositions as "the link between teachers' knowledge and beliefs and their behaviors and action" (p.81). Thus, if TEPs are required to assess dispositions to meet CAEP requirements, it is beneficial that TEPs and the CAEP Commission (2013) consider the assessment of dispositions as a contributor to dispositions development.

\section{References}

Banks, J. A., \& Banks, C. A. M. (Eds.). (2001). Multicultural education: Issues $\mathcal{E}$ perspectives. (4th ed.). New York: John Wiley \& Sons, Inc.
Bennett, C. (2001). Genres of research in multicultural education. Review of Educational Research, 71(2), 171-217.

Bercaw, L. A., Schussler, D. L., \&Stooksberry, L. M. (2010). Understanding teacher candidate dispositions: reflecting to build selfawareness. Journal of Teacher Education, 61(4), 350.

Boyer, J. B., \& Baptiste, Jr., H. P. (1996). Transforming the curriculum for multicultural understandings: A practitioner's handbook. San Francisco, CA: Caddo Gap Press. Cohen

Breese, L., \&Nawrocki-Chabin, R. (2007). Social cognitive perspective in dispositional development. In M. E. Diez\& J. Raths (Eds.), Dispositions in teacher education (pp. 31-53). Charlotte. NC: Information Age Publishing.

Buchmann, M. (1993). Role over person: Morality and authenticity in teaching. In $\mathrm{M}$. Buchmann\& R. Floden (Eds.), Detachment and concern: Conversations in the philosophy of teaching and teacher education (pp. 145157). New York: NY: Teachers College Press.

CAEP Commission (June 11, 2013). CAEP accreditation standards and evidence: Aspirations for Educator Preparation: Recommendations from the CAEP Commission on Standards and Performance Reporting to the CAEP Board of Directors. Author. Retrieved from http://caepnet.files.wordpress.com/2013 /02/commrpt.pdf

Carroll, D. (2005). Developing dispositions for teaching: Teacher education programs as moral communities of practice. The New Educator, 1. 81-100.

Carroll, D. (2012). Examining the development of dispositions for ambitious teaching: One teacher candidate's journey. The New Educator, 8, 38-64.

Council of the Accreditation of the Educator Preparation (2013). CAEP Accreditation Standards. Retrieved from: http://caepnet.files.wordpress.com/2013 /09/final_board_approved1.pdf

Department of Curriculum and Instruction C\& I (2012). Departmental vision statement. Retrieved from 
http://ci.education.nmsu.edu/files/2013 /07/CI_Dept_statement_8-20-12.pdf

Diez, M. E. (2006).Assessing dispositions: Context and questions. The New Educator, 2(1), 57-72.

Dispositions of in-service teachers: What we are learning. Paper presented at the Fourth Annual Symposium on Educator Dispositions, Northern Kentucky University, Highland Heights, KY.

Duplass, J. A., \& Cruz, B. C. (2010). Professional dispositions: What's a social studies education professor to do? The Social Studies, 101, 140-151.

Freire, P. (1970) Pedagogy of the oppressed. Translated by M. B. Ramos. London, Penguin.

Freire, P. (1988). Pedagogy of the oppressed. New York: Continuum.

Freire, P., \&Macedo, D. (1987). Literacy: Reading the word and the world. South Hadley, MA: Bergin \& Garvey.

Garmon, M. A. (2005). Six key factors for changing preservice teachers' attitudes/beliefs about diversity. Educational Studies, 38(3), 275-286.

Gay, G., \& Kirkland, K. (2003). Developing cultural critical consciousness and selfreflection in pre-service teacher education. Theory Into Practice, 42(3), 181-187.

Haberman, M. (1991). Can cultural awareness be taught in teacher education programs? Teaching Education, 4(1), 25-31.

Kirby, S., Greaves, L., \& Reid, C. (2006). Experience research social change: Methods beyond the mainstream ( $2^{\text {nd }}$ ed.). Peterborough, Ontario: Broadview Press.

Koerner, M.E. (1992). The cooperating teacher: An ambivalent participant in student teaching. Journal of Teacher Education, 64(3). 46-56. doi: $10.1177 / 002248719204300107$

Krueger, R.A., \& Casey, M.A. (2000). Focus groups: A practical guide for applied research (3rd ed.). Thousand Oaks, CA: Sage.
May, S. (Ed.). (1999). Critical multiculturalism: Rethinking multicultural and anti-racist education. Philadelphia, PA: Falmer Press

Merriam, S. B \& Associates (2002). Qualitative research in practice: Examples for discussion and analysis. San Francisco, CA: Jossey-Bass.

NCATE (2008a). Professional Standards for the Accreditation of Teacher Preparation Institutions. Retrieved from: http://www.ncate.org/Portals/0/docum ents/Standards/NCATE $\% 20 S t a n d a r d s \% 2$ 02008.pdf

NCATE (2008b). Glossary. Retrieved from: http://www.ncate.org/Standards/NCAT EUnitStandards/NCATEGlossary/tabid/477/Default .aspx

Nieto, S., \& Bode, P. (2008). Affirming diversity: The sociopolitical context of multicultural education. ( $5^{\text {th }}$ ed.). Boston, MA: Allyn and Bacon.

Patton, M. Q. (1990). Qualitative evaluation and research methods. Newbury Park, Calif: Sage Publications.

Sleeter, C., \& Grant, C. (1987). An analysis of multicultural education in the United States. Harvard Educational Review, 57(4), 421-445.

Wilson, J., Thornburg, R., \& Riley, G. (2005, November 17 - 18). Tracking the 